\title{
Effect of integrated use of cattle manure and inorganic fertilizers on tuber yield of potato in Ethiopia
}

\author{
T. Balemi* \\ Department of Plant Science and Horticulture, College of Agriculture and Veterinary Science, Ambo University, \\ P. O. Box 19, Ambo, Ethiopia. "Corresponding author: tesfayeb2005@yahoo.co.uk
}

\begin{abstract}
A field experiment was conducted to assess the effect of farmyard (cattle) manure (FYM) and inorganic nitrogen $(\mathrm{N})$ phosphorus $(\mathrm{P})$ fertilizers on growth and tuber yield of potato (Solanum tuberosum L.). The treatments consisted of factorial combination of 4 levels of FYM $\left(0.10,20\right.$ and $\left.30 \mathrm{t} \mathrm{h}^{-1}\right)$ and three levels of inorganic NP fertilizers $(0,33.3 \%, 66.6 \%$ recommended rates) laid out in a Randomized Complete Block Design (RCBD) replicated three times. Results demonstrated that the application of 20 or $30 \mathrm{t} \mathrm{ha}^{-1} \mathrm{FYM}+66.6 \%$ of the recommended inorganic NP fertilizers significantly increased total tuber yield over the application of full dose of inorganic NP fertilizers without FYM in vertisol whereas in nitosol, the highest level of FYM $\left(30 \mathrm{t} \mathrm{ha}^{-1}\right)+66.6 \%$ of the recommended inorganic NP fertilizers significantly improved total tuber yield over the application of full dose of inorganic NP fertilizers without FYM. The application of $10 \mathrm{t} \mathrm{ha}^{-1} \mathrm{FYM}+66.6 \%$ of the recommended inorganic NP fertilizers and 20 or $30 \mathrm{tha}^{-1} \mathrm{FYM}+33.3 \%$ of the recommended inorganic NP fertilizers gave a total tuber yield, which was on par with the tuber yield obtained due to the application of full dose of inorganic NP fertilizer alone, in both soils. Thus, the application of $10 \mathrm{tha}^{-1}$ and 20 or $30 \mathrm{tha}^{-1} \mathrm{FYM}$ resulted in a saving of $33.3 \%$ and $66.6 \%$ of the recommended NP fertilizers, respectively without significantly reducing the total tuber.
\end{abstract}

Keywords: Farmyard manure, inorganic fertilizer, main stem, tuber yield, potato, cattle manure, phosphorus, nitrogen. 


\section{Introduction}

The central highlands of Ethiopia, which is one of the major potato growing regions in the country, is dominated by two major soil types, vertisols and nitosols. Vertisols are known for their extensive cracking to the depth of $50 \mathrm{~cm}$ or more with seasonal drying and they occupy about 12.6 million ha in Ethiopia (Woldeab, 1987). Its poor physical properties such as poor drainage considerably restricted its productive potential, which can be improved with organic matter amendments. Nitosols on the other hand are characterized by low soil $\mathrm{pH}$ which renders the greater portion of such nutrients as phosphorus unavailable to crops due to favoured chemical fixation, thus ultimately lowering crop yield.

Potato (Solaneum tubrosum L.) is one of the major food crops in the mid and high altitude areas of Ethiopia. It is recognized as famine relief crop at the end of the rainy season when cereal crops are not ready for harvest, especially in the highland areas, where cereals mature after an extended period. Potato is grown in diverse soil types from black heavy soils (vertisols) to red soils (nitosols) in the central highlands of Ethiopia. Potatoes are annually grown on an area of about 160,000 hectares (World Potato Atlas, 2007). Despite its importance as a food crop, the productivity of this crop is as low as $10 \mathrm{tha}^{-1}$ mainly due to poor agronomic practices such as poor fertilization, the use of low quality tubers as planting materials and lack of improved adaptable cultivars (Tsegaw, 2006).

The growing human population demands improved crop productivity to solve the fragile food situation in the country. Today the price of chemical fertilizers in Ethiopia has escalated beyond the capacity of the majority of the farmers. Only in the past four to five years the cost of DAP and UREA fertilizers increased by three-fold. On the other hand, the indiscriminate use of chemical fertilizers alone, mainly during the maize-wheat production extension program of the last 15 years to meet country's food self sufficiency policy has resulted in the decline of soil productivity. Moreover, the use of chemical fertilizers alone might have also resulted in a possible depletion of essential micronutrients thereby resulting in an overall reduction in total crop productivity. The latter issue might be an answer for those farmers complaining of tremendous yield reduction despite the application of inorganic NP fertilizers to their farm.

The importance of farmyard manure is being realized again because of the high cost of commercial fertilizers and its long term adverse effect on soil chemical properties. Besides supplying macronutrients and micronutrients to the soil (Negassa et al., 2001; Tirol-Padre et al., 2007), farmyard manure also improves the physico-chemical properties of the soil (Tirol-Padre et al., 2007). However, unless it is integrated with inorganic fertilizers, the use of farmyard manure alone may not fully satisfy crop nutrient demand, especially in the year of application (Patel et al., 2009). Animal manures are also useful in improving the efficiency of fertilizer recovery thereby resulting in higher crop yield (Gedam et al., 2008).

Tolesaa and Friesen (2001) reported that the application of $25 \%$ recommended inorganic NP fertilizers + enriched FYM resulted in the highest marginal rate of return in maize indicating that the integrated approach can enable to save up to $75 \%$ of commercial fertilizers. Likewise, Bayu et al. (2006) also reported the possibility of saving up to $50 \%$ of the recommended NP fertilizers due to amendment with 5-15 $\mathrm{t} \mathrm{ha}^{-1}$ FYM to sorghum crop without significantly affecting the optimum possible yield that can be obtained with the application of full dose of inorganic NP fertilizers alone. Joy et al. (2005) reported the possibility of substituting up to $25 \%$ inorganic fertilizers with the 
application of $30 \mathrm{t} \mathrm{ha}^{-1}$ FYM while still maintaining the highest rhizome yield and quality of black musli. Ghosh and Sharma (1999) and Negassa et al. (2001) have shown improved grain yield in rice and maize, respectively, due to integrated use of FYM and inorganic NP fertilizers. Somanath and Syeenivasmuthy (2005) also similarly reported improved dry matter yield in Coleus forskohlii due to integrated use of FYM + NPK than using NPK alone. Farmyard manure also had a long-term effect in that the following crop in sequential cropping also benefit from the application (Sidhu et al., 2007).

Thus, the present study was designed to assess the influence of integrated use of farmyard manure and NP fertilizers on productivity of potato under two major soil types in mid altitude areas of West Shoa Zone, Ethiopia.

\section{Materials and methods}

\subsection{Description of the study area}

The study sites are located in Wesh Shoa Zone of Oromiya Regional State, Central Ethiopia. Ambo University Research Farm is located at $112 \mathrm{~km}$ while Guder Production Farm is located at 124 km, west of Addis Ababa at an altitude of 2060 and 1800 m.a.s.1, respectively. Ambo University Research Farm is characterized by pellic vertisol with poor drainage, average clay content of about $68.2 \%$ at a soil depth of 0-65 $\mathrm{cm}$ and a soil $\mathrm{pH}$ of 6.5 at similar soil depth. On the other hand, Guder Production Farm is characterized by nitosol with soil $\mathrm{pH}$ of 5.5-6.0. Both study areas have a unimodal rainfall pattern and average annual total rainfall ranging between $800-1200 \mathrm{~mm}$. The average maximum /minimum temperature during the experimental period ranged between $22-25^{\circ} \mathrm{C} / 9-13^{\circ} \mathrm{C}$ at Ambo Temperature was higher by $2-3^{\circ} \mathrm{C}$, and soil $\mathrm{pH}$ is slightly lower at Guder Production Farm.

\subsection{Experimental protocol, design and analysis}

A field experiment was conducted for two years (2003 and 2004 cropping seasons) at Ambo University Research Farm and Guder Production Farm during the rainy season without irrigation (June-October) using a potato cultivar CIP/384321.3 to asses the effect of integrated use of FYM and NP fertilizers on growth and tuber yield of potato. Cattle manure collected from the dairy farm of Ambo University was allowed to decompose for a couple of months and was mixed thoroughly before using for the experiment. The treatments consisted of factorial combinations of $4 \mathrm{lev}$ els of FYM $\left(0,10,20\right.$ and $\left.30 \mathrm{t} \mathrm{ha}^{-1}\right)$ and 3 levels of inorganic NP fertilizers $(0,33.3 \%$ and $66.6 \%$ of the recommended rates). The recommended doses were 114 and $195 \mathrm{~kg} / \mathrm{ha}$ DAP for vertisol and nitosol, respectively and 185 and $152 \mathrm{~kg} / \mathrm{ha}$ Urea for vertisol and nitosol, respectively. Additional full dose of inorganic NP fertilizers without FYM was also used as a standard control for comparison. The 0: 0, FYM: inorganic NP fertilizer was used as an absolute control. The treatments were laid out in a Randomized Completely Block Design (RCBD) with three replications. Each level of FYM was weighed (on dry weight basis) and applied to the respective experimental plots and incorporated into the soil 4 weeks before planting the potato tubers. Nitrogen and phosphorus fertilizers were applied in the form of urea and DAP, respectively. Recommended doses of phosphorus were applied at planting whereas nitrogen was split twice: half was applied at planting and the remainder was applied 30 days after planting. The number of main stems per plant was counted at $50 \%$ flowering. The tubers were carefully harvested by digging after $50 \%$ of the tops died. Data was analysed using the PROC GLM procedure of SAS (SAS version 9.1, Institute INC., Cary, USA). Treatment means were compared at $\alpha=0.05$ probability level according to Tukey test. 


\section{Results}

\subsection{Effect of treatments on total tuber yield}

Total tuber yield (Table 1) was significantly influenced by the FYM + NP fertilizers treatments $(\mathrm{P}<0.001)$. Unlike on vertisol, there was an interaction effect of FYM and NP fertilizer rates on nitosol. In vertisol, the application of 20 to $30 \mathrm{tha}^{-1} \mathrm{FYM}+66.6 \%$ of the recommended inorganic NP fertilizers gave significantly higher total tuber yield than full dose of inorganic NP fertilizers without FYM. On the other hand, in nitosol $30 \mathrm{t} \mathrm{ha}^{-1} \mathrm{FYM}+66.6 \%$ of the recommended inorganic NP fertilizers gave significantly higher total tuber yield than full dose of inorganic NP fertilizers without FYM. The application of $10 \mathrm{t} \mathrm{ha}^{-1} \mathrm{FYM}+66.6 \%$ of the recommended inorganic NP fertilizers and 20 to $30 \mathrm{t} \mathrm{ha}^{-1} \mathrm{FYM}+33.3 \%$ of the recommended inorganic NP fertilizers gave a total tuber yield which was on par with the tuber yield obtained due to applying full dose of inorganic NP fertilizers alone, in both soil types. The results demonstrated that the application of $10 \mathrm{tha}^{-1}$ and 20 or $30 \mathrm{tha}^{-1} \mathrm{FYM}$ resulted in a saving of $33.3 \%$ and $66.6 \%$ commercial NP fertilizers, respectively without significantly reducing the total tuber yield. All the treatments significantly improved the total tuber yield compared to the absolute control where there was no any form of external fertilizer application. In the absence of chemical fertilizers application, the total tuber yield was significantly increased as FYM was increased from 0 to $20 \mathrm{tha}^{-1}$, but further increasing the amount of FYM to $30 \mathrm{tha}^{-1}$ did not significantly increase the total tuber yield under both soil types during both cropping seasons. However, the application of FYM alone at all levels could not significantly improve the total tuber yield over the standard control, unlike over the absolute control in both soil types and during both cropping seasons (Table 1).

Table 1. Effect of FYM and NP rates on total tuber yield ( $\mathrm{q} \mathrm{ha}^{-1}$ ) of potato under two major soil types in West Shoa Zone, Ethiopia.

\begin{tabular}{|c|c|c|c|c|c|}
\hline \multirow{3}{*}{$\begin{array}{l}\text { FYM } \\
\left(\mathrm{t} \mathrm{ha}^{-1}\right)\end{array}$} & \multirow{3}{*}{$\begin{array}{l}\text { (\% recommended } \\
\text { NP fertilizers) }\end{array}$} & \multicolumn{4}{|c|}{ Total Tuber Yield $\left(\mathrm{q} \mathrm{ha}^{-1}\right)$} \\
\hline & & \multicolumn{2}{|c|}{2003 cropping season } & \multicolumn{2}{|c|}{2004 cropping season } \\
\hline & & Vertisol & Nitosol & Vertisol & Nitosol \\
\hline \multirow{3}{*}{0} & 0 & $185.8^{\mathrm{h}}$ & $222.7^{\mathrm{h}}$ & $176.2^{\mathrm{f}}$ & $218.6^{\mathrm{h}}$ \\
\hline & $33.3 \%$ & $291.4^{\mathrm{fg}}$ & $417.1^{\mathrm{f}}$ & $265.4^{\mathrm{e}}$ & $410.0^{\mathrm{f}}$ \\
\hline & $66.6 \%$ & $381.9^{\mathrm{cd}}$ & $484.9^{\mathrm{de}}$ & $349.8^{\mathrm{cd}}$ & $466.8^{\mathrm{de}}$ \\
\hline \multirow{3}{*}{10} & 0 & $249.9^{\mathrm{g}}$ & $345.4^{\mathrm{g}}$ & $242.4^{\mathrm{e}}$ & $330.4^{\mathrm{g}}$ \\
\hline & $33.3 \%$ & $342.0^{\text {def }}$ & $450.4^{\mathrm{ef}}$ & $333.9^{\mathrm{d}}$ & $443.5^{\text {ef }}$ \\
\hline & $66.6 \%$ & $437.9^{\mathrm{bc}}$ & $524.7^{\mathrm{cd}}$ & $408.4^{\mathrm{b}}$ & $504.1^{\mathrm{cd}}$ \\
\hline \multirow{3}{*}{20} & 0 & $321.0^{\mathrm{ef}}$ & $436.2^{\text {ef }}$ & $319.4^{\mathrm{d}}$ & $423.9^{\text {ef }}$ \\
\hline & $33.3 \%$ & $435.0^{\mathrm{bc}}$ & $519.8^{\mathrm{cd}}$ & $390.8^{\mathrm{bc}}$ & $511.3^{\mathrm{cd}}$ \\
\hline & $66.6 \%$ & $502.1^{\mathrm{a}}$ & $595.9^{\mathrm{b}}$ & $481.7^{\mathrm{a}}$ & $573.9^{\mathrm{b}}$ \\
\hline \multirow{3}{*}{30} & 0 & $360.1^{\mathrm{de}}$ & $462.9^{\text {def }}$ & $343.6^{\mathrm{cd}}$ & $445.1^{\mathrm{ef}}$ \\
\hline & $33.3 \%$ & $444.2^{\mathrm{b}}$ & $555.6^{\mathrm{bc}}$ & $424.6^{\mathrm{b}}$ & $541.2^{\mathrm{bc}}$ \\
\hline & $66.6 \%$ & $534.2^{\mathrm{a}}$ & $670.0^{\mathrm{a}}$ & $510.7^{\mathrm{a}}$ & $631.1^{\mathrm{a}}$ \\
\hline \multicolumn{2}{|c|}{$\begin{array}{l}\text { Standard control } \\
\text { (full NP without FYM) }\end{array}$} & $444.9^{\mathrm{b}}$ & $582.4^{\mathrm{bc}}$ & $424.07^{\mathrm{b}}$ & $557.2^{\mathrm{bc}}$ \\
\hline \multicolumn{2}{|c|}{$\operatorname{LSD}(\alpha=0.05)$} & 56.4 & 65.6 & 47.5 & 54.8 \\
\hline
\end{tabular}


3.2 Effect of treatments on days to $50 \%$ flowering and number of main stems per plant

Days to $50 \%$ flowering ranged between 51.3 to 54 on vertisol and 46 to 49 on nitosol; however there was not significant difference between treatments under both soil types (Table 2). Except for the absolute control, where the number of main stems per plant was inferior, all the other treatments did not differ in influencing the number of main stems per plant under both soil types during both cropping seasons (Table 2).

Table 2. Effect of FYM and NP rates on days to $50 \%$ flowering and number of main stems per plant of potato under two major soil types in West Shoa Zone, Ethiopia.

\begin{tabular}{|c|c|c|c|c|c|}
\hline \multirow{2}{*}{$\begin{array}{l}\text { FYM } \\
\left(\mathrm{t} \mathrm{ha}^{-1}\right)\end{array}$} & \multirow{2}{*}{$\begin{array}{l}\text { (\% recommended } \\
\text { NP fertilizers) }\end{array}$} & \multicolumn{2}{|c|}{ Days to $50 \%$ flowering } & \multicolumn{2}{|c|}{ Number of main stems per plant } \\
\hline & & Vertisol & Nitosol & Vertisol & Nitosol \\
\hline \multirow{3}{*}{0} & 0 & $54.0^{\mathrm{a}}$ & $49.0^{\mathrm{a}}$ & $4.0^{\mathrm{b}}$ & $4.3^{\mathrm{b}}$ \\
\hline & $33.3 \%$ & $51.3^{\mathrm{a}}$ & $47.0^{\mathrm{a}}$ & $4.4^{\mathrm{ab}}$ & $4.8^{\mathrm{ab}}$ \\
\hline & $66.6 \%$ & $52.0^{\mathrm{a}}$ & $48.0^{\mathrm{a}}$ & $5.2^{\mathrm{ab}}$ & $5.5^{\mathrm{ab}}$ \\
\hline \multirow{3}{*}{10} & 0 & $52.0^{\mathrm{a}}$ & $47.0^{\mathrm{a}}$ & $4.8^{\mathrm{ab}}$ & $4.7^{\mathrm{ab}}$ \\
\hline & $33.3 \%$ & $51.7^{\mathrm{a}}$ & $47.7^{\mathrm{a}}$ & $5.3^{\mathrm{ab}}$ & $5.4^{\mathrm{ab}}$ \\
\hline & $66.6 \%$ & $52.7^{\mathrm{a}}$ & $46.0^{\mathrm{a}}$ & $5.5^{\mathrm{ab}}$ & $5.8^{\mathrm{ab}}$ \\
\hline \multirow{3}{*}{20} & 0 & $53.0^{\mathrm{a}}$ & $47.7^{\mathrm{a}}$ & $5.1^{\mathrm{ab}}$ & $5.3^{\mathrm{ab}}$ \\
\hline & $33.3 \%$ & $52.0^{\mathrm{a}}$ & $46.3^{\mathrm{a}}$ & $5.5^{\mathrm{ab}}$ & $5.8^{\mathrm{ab}}$ \\
\hline & $66.6 \%$ & $52.0^{\mathrm{a}}$ & $47.7^{\mathrm{a}}$ & $5.8^{\mathrm{ab}}$ & $6.3^{\mathrm{a}}$ \\
\hline \multirow{3}{*}{30} & 0 & $54.0^{\mathrm{a}}$ & $48.0^{\mathrm{a}}$ & $5.3^{\mathrm{ab}}$ & $5.8^{\mathrm{ab}}$ \\
\hline & $33.3 \%$ & $51.7^{\mathrm{a}}$ & $46.0^{\mathrm{a}}$ & $5.5^{\mathrm{ab}}$ & $6.1^{\mathrm{ab}}$ \\
\hline & $66.6 \%$ & $52.0^{\mathrm{a}}$ & $46.7^{\mathrm{a}}$ & $6.4^{\mathrm{a}}$ & $6.5^{\mathrm{a}}$ \\
\hline \multicolumn{2}{|c|}{$\begin{array}{l}\text { Standard control } \\
\text { (full NP without FYM) }\end{array}$} & $52.0^{\mathrm{a}}$ & $46.3^{\mathrm{a}}$ & $5.6^{\mathrm{ab}}$ & $6.2^{\mathrm{a}}$ \\
\hline \multicolumn{2}{|c|}{$\operatorname{LSD}(\alpha=0.05)$} & 3.22 & 3.51 & 2.05 & 1.8 \\
\hline
\end{tabular}

\subsection{Effect of main factors}

\section{Effect of FYM}

Under both soil types, the tuber yield was significantly influenced by the levels of FYM applied (Figure $1 \mathrm{~A} \& \mathrm{C}$ ) during both years experiment. The pattern of FYM influence on tuber yield was similar for both soil types as well as both cropping seasons. In all cases the total tuber yield increased with increasing level of FYM and significantly differed at all levels of FYM.
On the other hand, the effect of FYM levels on the number of main stems followed similar pattern to that of the total tuber yield. In nitosol, the application of 0 and $10 \mathrm{tha}^{-1}$ on one hand, and 20 and $30 \mathrm{tha}^{-1}$ on the other hand did not significantly differ from each other in influencing the number of main stem per plant (Figure 2A). In vertisol, the absence of FYM application resulted in lower number of main stems compared to the application of 20 and $30 \mathrm{tha}^{-1}$ FYM. FYM did not affect the number of days to $50 \%$ flowering under both soil types (data not presented). 

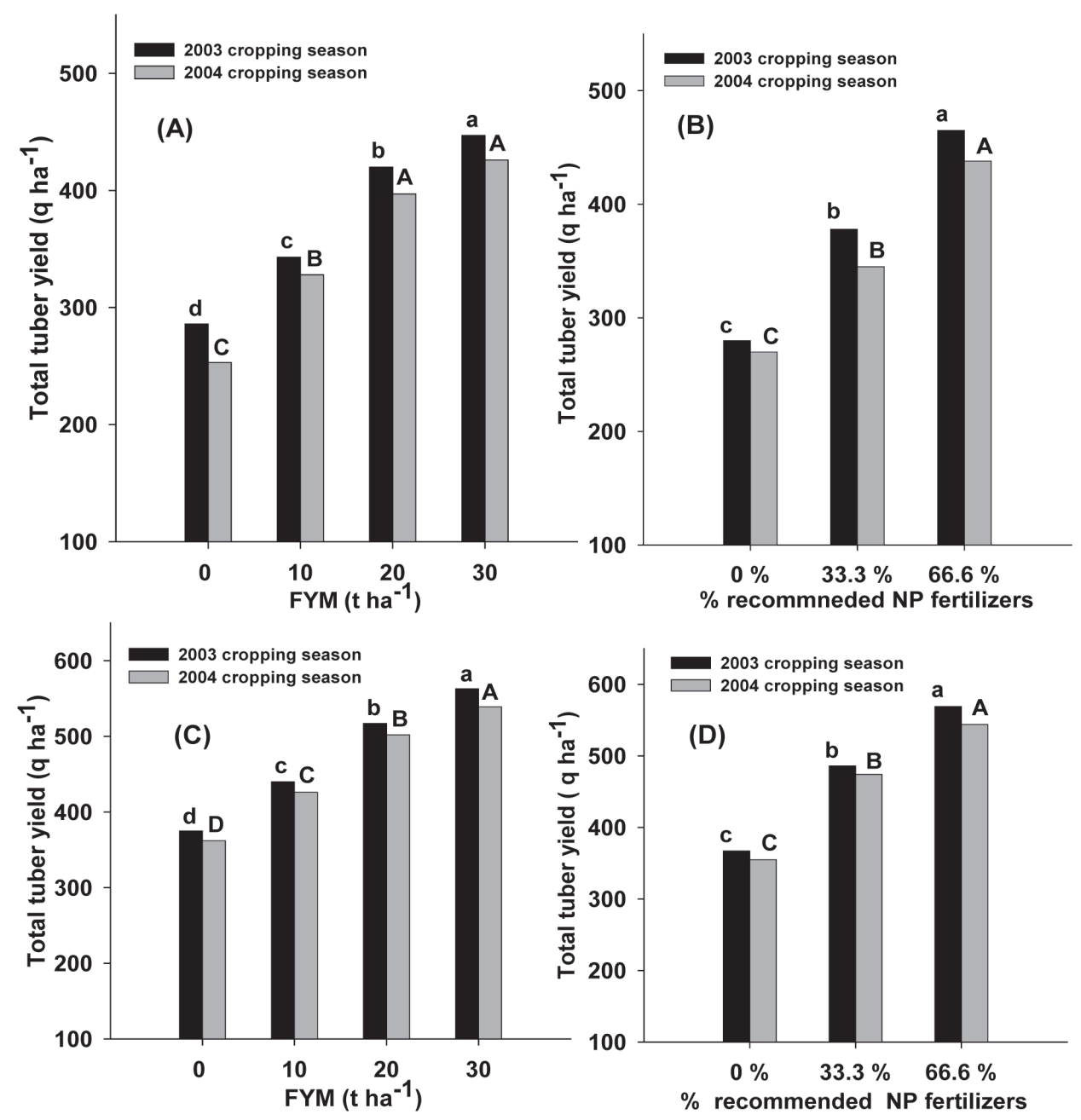

Figure 1. Effect of FYM and NP fertilizers rate on total tuber yield in vertisol (A and B, respectively) and nitosol (C and D, respectively). Similar coloured bars followed by different letters are significantly different at 0.05 probability level, Tukey test. 


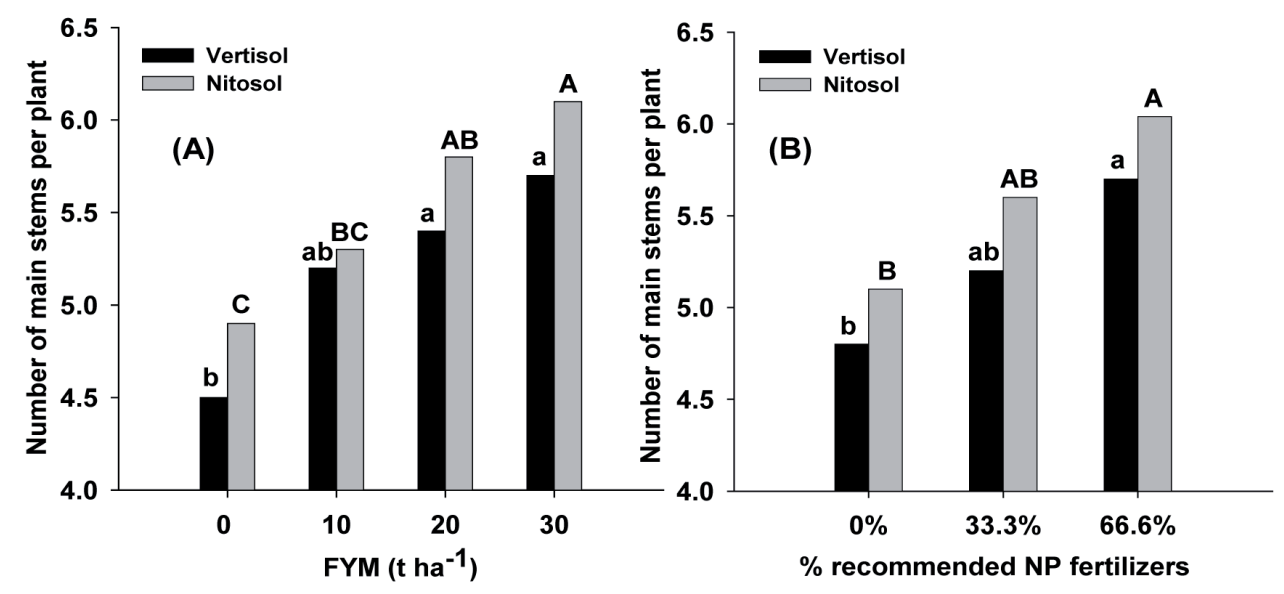

Figure 2. Effect of FYM (A) and inorganic NP fertilizers rate (B) on number of main stems per plant. Similar coloured bars followed by different letters are significantly different at 0.05 probability level, Tukey test.

\section{Effect of inorganic NP fertilizers}

The effect of inorganic NP fertilizer rate on total tuber yield followed similar trend under both soil types and during both cropping seasons (Figure 1B \& D). At all levels of inorganic NP fertilizers rate, the total tuber yield differed significantly. The application of $66.6 \%$ recommended inorganic NP fertilizers resulted in the highest total tuber yield on both soil types and during both cropping seasons. On the other hand, the absence of inorganic fertilizers application resulted in the lowest number of main stems per plant compared to the application of $33.3 \&$ and $66.6 \%$ inorganic NP fertilizers, but both of these rates did not differ from each other in influencing the number of main stems per plant. The number of days to $50 \%$ flowering was not significantly affected by the application of inorganic NP fertilizers under both soil types (data not presented).

\section{Discussion}

Supplementing $66.6 \%$ of the recommended inorganic fertilizers with $20 \mathrm{t} \mathrm{ha}^{-1} \mathrm{FYM}$ was sufficient to significantly increase the total tuber yield over the standard control in vertisol whereas the quantity of FYM that should supplement the same level of inorganic NP fertilizers in nitosol to significantly increase the tuber yield over the standard control was $30 \mathrm{t} \mathrm{ha}^{-1}$. Thus, nitosol demanded the application of more quantity of FYM in order to significantly boost total tuber yield as compared to vertisol under similar level of inorganic NP fertilizers application. This could probably be because soil physico-chemical characteristics of vertisol such as drainage, and $\mathrm{N}$ and $\mathrm{P}$ mineralization rate responded more favourably even to lower FYM application compared to nitosol. The application of 30 $\mathrm{t} \mathrm{ha}^{-1}$ FYM on average enhanced the total tuber yield over zero FYM during both years by $50 \%$ and $63 \%$, 
respectively on niosol and vertisol. Similarly, Sidhu et al. (2007) reported 29\% yield increase due to supplementing $50 \mathrm{t} \mathrm{ha}^{-1}$ in potato over FYM untreated control. The application of any of the FYM levels (10, 20, $30 \mathrm{tha}^{-1}$ ) alone improved the total tuber yield only over the absolute control but could not significantly improve the total tuber yield over the standard control signifying that unless it is integrated with inorganic fertilizers, FYM alone can not significantly boost tuber yield. This is perhaps because the FYM released nutrient very slowly and the released nutrients in the year of application may did not satisfy the crop nutrient demand. However, total tuber yield was significantly different for each FYM level and increased linearly with increasing FYM levels in both soil types. This shows that potato responds considerably to FYM application suggesting that potato growers can use for increased tuber yield. In agreement with the result of the present study, various studies have also shown the positive effects of FYM amendment with inorganic fertilizers in boosting crop yield (Ghosh and Sharma 1999; Negassa et al. 2001; Tolesaa and Friesen 2001; Joy et al. 2005; Somanath and Syeenivasmuthy 2005; Bayu et al., 2006). However, Patel et al. (2000) did not observe any significant effect of FYM application on the yield of Chicory, which contradicts with the present report as well as with the reports of aforementioned authors. The improved total tuber yield with increased level of FYM application in this study was probably related to increased available $\mathrm{P}$, mineralized $\mathrm{N}$ and improved cation exchange capacity of the soil as has been described by Tirol-Padre et al. (2007). In agreement with the results of the present study, Roy et al. (2001) reported that amendment of FYM with inorganic fertilizers did not significantly improve the number of main stems in potato over the treatment without FYM. The 5 days early flowering under nitosol at Guder compared to vertisol at Ambo in this study was due to the relatively warmer weather that prevailed at Guder during the experimental period.

\section{Conclusions}

The results of the present investigation demonstrated that the integrated use of FYM and commercial NP fertilizers significantly enhanced potato tuber yield as compared to the use of each fertilizer source separately, thus potentially reducing the cost of production. Considering the three-fold increase of commercial fertilizer price in the country in the past $4-5$ years, the possibility of substituting $66.6 \%$ of the recommended inorganic fertilizers with the application of 20-30 t ha $^{-1}$ FYM, as observed in the present study must be a great benefit to those farmers with sufficient livestock holdings. Additionally, the integrated approach has along term benefit in that it also improves the physico-chemical properties of the soil for sustainable crop production.

\section{Acknowledgement}

The Author acknowledges Mrs. Etagegn Teshome, for her technical assistance in the execution of the experiment and for the field data collection. I would also like to thank Ambo University for financing this research.

\section{References}

Bayu, W., Rethman, N.F.G., Hammes, P.S., Alemu, G. 2006. Effect of Farmyard Manure and Inorganic Fertilizers on Sorghum Growth, Yield and Nitrogen Use in Semi-arid Areas of Ethiopia. Journal of Plant Nutrition 29, 391-407.

Gedam, V.B., Rametke, J.R., Rudragouda, Power, M.S. 2008. Influence of organic manures on yield, nutrient uptake and change in physico-chemical properties of soil after harvest of groundnut. Crop Research, 36,111-114. 
Ghosh, A., Sharma, A.R. 1999. Effect of combined use of organic manure and nitrogen fertilizer on the performance of rice under flood-prone lowland conditions. The Journal of Agricultural Science 132, 461-465.

Joy, P.P., Savithri, K.E., Mathew, S., Thomas, J., Kurien, K. 2005. Effect of sole and combined application of FYM and fertilizer on growth, yield and quality of black musli (Curculigo orchioides). Journal of Medicinal and Aromatic Plant Sciences 27, 454-46.

Negassa, W., Negisho, K., Friesen, D.K., Ransom, J., Yadessa, A. 2001. Determination of Optimum Farmyard Manure and NP Fertilizers for Maize on Farmers Field. Seventh Eastern and Southern Africa Regional Maize Conference. $11^{\text {th }}-15^{\text {th }}$ February. 387-393.

Patel, J.R., Patel, J.B., Upadhyay, P.N., Usadadia, V.P. 2000. The effect of various agronomic practices on the yield of Chicory (Cichorium intybus). Journal of agricultural Science 135, 271-278.

Roy, S.K., Sharma, R.C., Trehan, S.P. 2001. Integrated nutrient management by using farmyard manure and fertilizers in potato-sunflower-paddy rice rotation in the Punjab. Journal of Agricultural Science 137, 271-278.

Sidhu, A.S., Thind, S.S., Sekhon, N.K., Hira, G.S. 2007. Effect of Farmyard Manure and P applica- tion to potato on available $\mathrm{P}$ and Crop Yield of Potato-Sunflower Sequence. Journal of Sustainable Agriculture 3, 5-15.

Somanath, B.S., Sreenivasmurthy, C.A. 2005. Influence of FYM and inorganic fertilizer (NPK) and sources of potassium on the yield of Coleus forskohlii. Journal of Medicinal and Aromatic Plant Sciences 27, 16-19.

Tirol-Padre A., Ladha J.K., Regmi AP, Bhandari A.L., Inubushi K. 2007. Organic Amendment Affect Soil Parameters in Two Long-Term Rice-Wheat Experiments. Soil Sci Soc Am J. 71, 442-452.

Tolessa, D., Friensen, D.K. 2001. Effect of Enriching Farmyard Manure with Mineral fertilizer on grain yield of Maize at Bako, Western Ethiopia. Seventh Eastern and Southern Africa Regional Maize Conference. $11^{\text {th }}-15^{\text {th }}$ February. 335-337.

Tsegaw, T. 2006. Response of Potato to Paclobutrazol and Manipulation of Reproductive Growth under Tropical Condition. Ph D dissertation, University of Pretoria etd, South Africa.

Woldeab, A. 1987. Physical property of Ethiopian soil. A paper presented at workshop held at Rylla's Hotel, Malawi 2003: Proceedings of workshop on utilization of agricultural byproducts as livestock feeds in Africa. Blantrye, Malawi.

World Potato Atlas. 2007. 
